\title{
316L Stainless Steel Manufactured by Selective Laser Melting and Its Biocompatibility with or without Hydroxyapatite Coating
}

\author{
Jiapeng Luo ${ }^{1,2,+}$, Xiao Jia ${ }^{2,3,+} \mathbb{D}$, Ruinan $\mathrm{Gu}^{2}$, Peng Zhou ${ }^{2}$, Yongjiang Huang ${ }^{1}$, Jianfei Sun ${ }^{1, *}$ \\ and Ming Yan ${ }^{2, *}$ \\ 1 School of Materials Science and Engineering, Harbin Institute of Technology, Harbin 150001, China; \\ luojp-hit@foxmail.com (J.L.); yjhuang@hit.edu.cn (Y.H.) \\ 2 Department of Materials Science and Engineering and Shenzhen Key Laboratory for Additive \\ Manufacturing of High-performance Materials, Southern University of Science and Technology, \\ Shenzhen 518055, China; jiaxiaosa@outlook.com (X.J.); gurn@mail.sustc.edu.cn (R.G.); \\ zhoupeng85723@163.com (P.Z.) \\ 3 Department of Electrical and Computer Engineering, National University of Singapore, 4 Engineering \\ Drive 3, Singapore 117583, Singapore \\ * Correspondence: jfsun@hit.edu.cn (J.S.); yanm@sustc.edu.cn (M.Y); \\ Tel.: +86-451-8641-8317 (J.S.); +86-755-8801-8967 (M.Y.) \\ + These authors contributed equally to this work.
}

Received: 2 June 2018; Accepted: 10 July 2018; Published: 18 July 2018

\begin{abstract}
To fabricate metallic 316L/HA (hydroxyapatite) materials which meet the requirements of an implant's mechanical properties and bioactivity for its function as human bone replacement, selective laser melting (SLM) has been employed in this study to prepare a 316L stainless steel matrix, which was subsequently covered with a hydroxyapatite (HA) coating using the sol-gel method. High density (98.9\%) as-printed parts were prepared using a laser power of $230 \mathrm{~W}$ and a scanning speed of $800 \mathrm{~mm} / \mathrm{s}$. Austenite and residual acicular ferrite existed in the microstructure of the as-printed 316L stainless steel, and the sub-grain was uniform, whose primary dendrite spacing was around $0.35 \mu \mathrm{m}$. The as-printed 316L stainless steel showed the highest Vickers hardness, elastic modulus, and tensile strength at $\sim(\sim$ means about; same applies below unless stated otherwise $)$ $247 \mathrm{HV}, \sim 214.2 \mathrm{GPa}$, and $\sim 730 \mathrm{MPa}$, respectively. The elongation corresponding to the highest tensile strength was $\sim 38.8 \%$. The 316L/HA structure, measured by the Relative Growth Rate (RGR) value, exhibited no cell cytotoxicity, and presented better biocompatibility than the uncoated as-printed and as-cast 316L samples.
\end{abstract}

Keywords: selective laser melting; 316L stainless steel; hydroxyapatite; biocompatibility

\section{Introduction}

With the continual progress of medical technology as well as the extension of human life, it is probable that there will be a huge potential demand for and research interest in metallic body implants [1,2]. One of the most commonly used but expensive metallic biomaterials is titanium (alloy), which is utilized in many circumstances, such as interlocking nails, hip prosthesis, and facial implants. Although biomedical titanium alloy shows relatively good biocompatibility and admirable corrosion and wear resistance, its high price and possible toxicity is likely to limit its widespread use in bone operations [3-6]. Nowadays, 316L stainless steel is used as a more cost-efficient alternative for implant biomaterial, and piques more interest due to its excellent corrosion resistance and great mechanical properties. As reported in previous papers, the material has been successful in making 
implants to replace shoulders, knees, and other body parts of the human being [7-9]. However, it is difficult to induce good attachment and growth of bone cells from 316L stainless steel and it also has no bioactive capabilities, which increases the likelihood for it to lead to loosening of the implant and premature failure [10-12]. The HA coating, however, is likely to provide excellent bioactivity and biocompatibility to metallic implants [13-15].

For individual patients, mass-produced implants may not completely fulfill their needs. Customized implants, with geometry deriving from their own magnetic resonance imaging (MRI) data, are urgently needed [16]. SLM, which is a powder-bed-based additive manufacturing technology, can be used to selectively melt metal powders layer by layer through a highly focused and computer-controlled laser beam $[17,18]$. It has been used to successfully prepare many kinds of metallic biomaterials, such as stainless steel, alloys of titanium, magnesium, and medical noble metals, and compared with some of the more traditional approaches, it provides superior mechanical properties and a relatively simpler manufacturing process $[19,20]$.

In retrospect, some studies around SLM-processed 316L stainless steel with different laser parameters and lattice structure designs have been undertaken [21-23]. In order to testify its feasibility as an implant, simple cytotoxicity and biocompatibility tests were conducted while comparing different manufacturing and post-processing methods [24-28]. However, these can hardly solve the problem of poor bioactivity, and may even cause a failure of metallic implants. As a time-honored bio ceramic which realizes higher osteoblast activity, HA material is currently quite popular for its special applications in regenerative implants and bone void fillers [29]. Metallic implants, with the help of HA coating, can improve the new bone formation process and promote bone healing, as the bio ceramic material is able to accelerate osteoblast differentiation and also increase collagen levels [30,31]. In order to avoid secondary phases (such as calcium oxide, tricalcium phosphate, tetra calcium phosphate, etc.) in high-temperature processes and also to generate superior structural integrity, the sol-gel method is used to produce homogeneous HA coating onto the as-printed 316L stainless steel substrate [32-35]. Hence, in this work, the metallic 316L/HA material, with proper bioactivity and mechanical properties, was introduced to satisfy the corresponding requirements of bone implants.

The samples of 316L stainless steel as substrate material with high relative density were additively manufactured by SLM. The microstructure and mechanical properties of the fabricated samples have been investigated in detail. Furthermore, the 316L/HA samples were fabricated using the sol-gel method, and the biocompatibility of the 316L/HA samples were also tested and compared with that of the uncoated 316L stainless steel. This study demonstrates that it is possible to enhance the bioactivity of the as-printed 316L steel by HA coating.

\section{Experimental Section}

\subsection{Material Preparation and Characterization}

The experimental procedure is shown in Figure 1. The 316L stainless steel powders were purchased from Sandvik Osprey Co. Ltd., and the chemical composition of the powders is shown in Table 1 (in wt \%). The size distribution of the powder was analyzed by the LS-609 laser particle size analyzer (Malvern Instruments). The morphology of the 316L stainless steel powders was acquired by the TESCAN MIRA3 field-emission Scanning Electron Microscopy (SEM, operated at $10 \mathrm{kV}$ ). The as-cast samples were purchased from Wuxi Longyunxiang Steel Company (Wuxi, Jiangsu, China). The Electron Backscattered Diffraction (EBSD) mapping was carried out by the same SEM. The SEM parameters were $15 \mathrm{kV}, 60 \mu \mathrm{m}$ aperture, with a high current mode. SEM mapping settings were $0.05-0.5 \mu \mathrm{m}$ step size and 1000-5000 grains, with the grain boundary definition set as $10^{\circ}$. Grain size measurements were obtained using data for all grains in a single map. The nano-hydroxyapatite powders were purchased from Beijing Dk Nano Technology Co. Ltd. (Beijing, China). The morphology of the nano-hydroxyapatite powders was obtained by Tescan F30 Transmission Electron Microscope (TEM, Boston, MA, USA). 

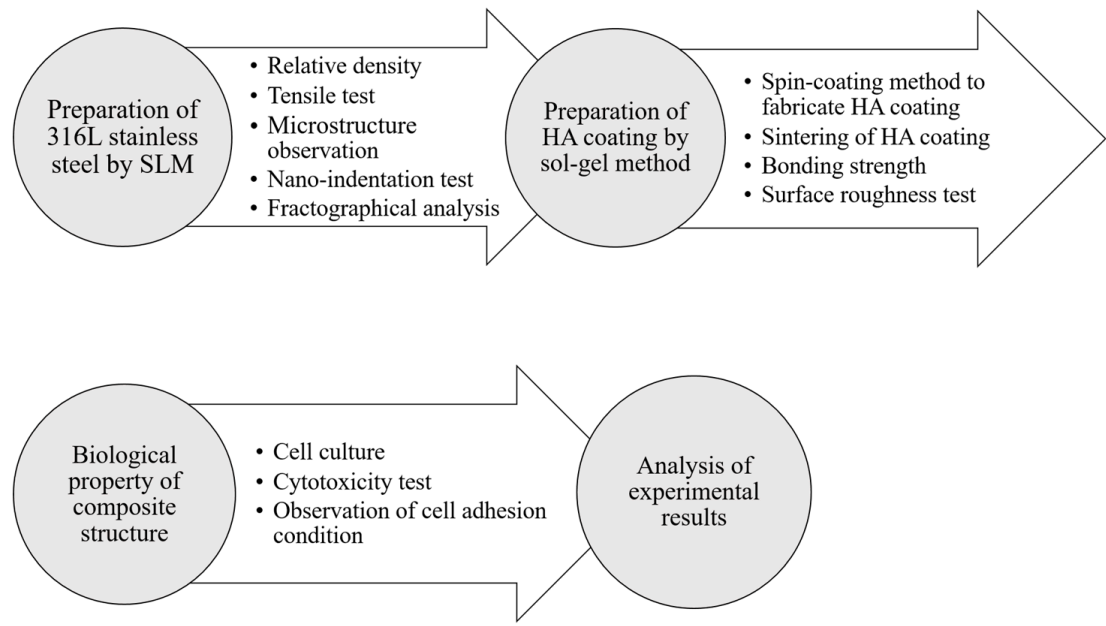

Figure 1. A flow chart of the work.

Table 1. Chemical composition of 316L stainless steel powders studied in this work (wt \%).

\begin{tabular}{cccccc}
\hline $\mathbf{C r}$ & $\mathbf{1 6 - 1 8}$ & $\mathbf{N i}$ & $\mathbf{1 2 - 1 4}$ & Mo & $\mathbf{2 - 3}$ \\
\hline $\mathrm{Mn}$ & $\leq 2$ & $\mathrm{Si}$ & $\leq 0.75$ & $\mathrm{C}$ & $\leq 0.1$ \\
$\mathrm{P}$ & $\leq 0.1$ & $\mathrm{~S}$ & $\leq 0.1$ & $\mathrm{Fe}$ & remainder \\
\hline
\end{tabular}

A Concept Laser M2 machine (Lichtenfels, Germany), equipped with a 400 W Yb: YAG continuous wavelength fiber laser ( $50 \mu \mathrm{m}$ beam size) was used to fabricate the samples under a high-purity Ar atmosphere containing no more than 100 ppm environmental oxygen. The 316L stainless steel tensile samples (Figure 2 ) were additively manufactured through varying processing parameters of laser power $(P, 140-290 \mathrm{~W})$. The layer thickness $(D, \mu \mathrm{m})$ was kept constant at $30 \mu \mathrm{m}$, and the scanning speed $(v, \mathrm{~mm} / \mathrm{s})$ was fixed at $800 \mathrm{~mm} / \mathrm{s}$. The STL files of the samples were generated by MAGICS software (Materialise, Leuven, Belgium), and the chess scanning strategy was adopted in this experiment. The chess scanning strategy is one of the most commonly used scanning strategies in $3 \mathrm{D}$ printing. When this strategy is used, the area to be printed is divided into multiple squares, similar to a chessboard. The laser scanning directions are placed perpendicular to each other in each adjacent square.
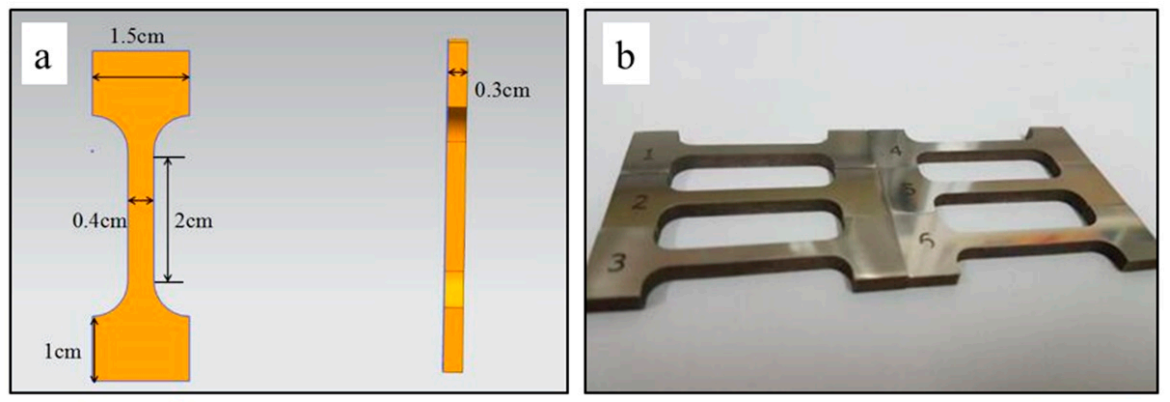

Figure 2. (a) Dimensional drawing and (b) optical image of tensile samples.

The relative density of the samples was measured by using the Archimedes' method. Five measurements were made for each sample, and the results were averaged. Relative density was calculated through the relation [36]:

$$
\mathrm{RD}=\frac{\mathrm{m}_{0} \cdot \rho_{\text {water }}}{\rho_{1} \cdot\left(m_{0}-m_{1}\right)} \times 100 \%
$$


where $m_{0}$ is the samples' mass $(\mathrm{g})$ in air, $m_{1}$ is the samples' mass $(\mathrm{g})$ in water, $\rho_{\text {water }}$ is the density of distilled water which was $0.9982 \mathrm{~g} / \mathrm{cm}^{3}$, and $\rho_{1}$ is the density of standard steel which was $7.98 \mathrm{~g} / \mathrm{cm}^{3}$ [37]. After this, the "best parameter" was acquired from the densest sample. The Vickers hardness was measured on the polished samples through an HXD-1000TMC/LCD microscopic Webster hardness tester (Yongxiang, Shanghai, China) with a $500 \mathrm{~N}$ load and dwell time of $15 \mathrm{~s}$. Seven positions were measured randomly on each sample, and the deviation in these measurements was less than $\pm 0.4 \%$.

Phase constitution was analyzed by the Advance ECO X-ray diffractometer (XRD, $\mathrm{Cu} \mathrm{K}_{\alpha}$ radiation, wavelength $1.4506 \AA$, at $50 \mathrm{kV}$ and $300 \mathrm{~mA}$, Karlsruhe, Germany). Continuous scanning at a speed of $1.5^{\circ} / \mathrm{min}$ was used from a $2 \theta$ angle of $30^{\circ}$ to $90^{\circ}$.

The tensile samples were tested using an MTS-CMT microcomputer-controlled universal testing machine (The United States) at a strain rate of $0.0005 / \mathrm{s}$. There were five tensile samples tested for each condition, and the results of the tensile test were averaged. During the tensile tests, the load-displacement data was recorded and the elastic modulus acquired. Microscopical observations of the fracture surface were acquired by the SEM.

The nano-hydroxyapatite was first dissolved in absolute ethyl alcohol at room temperature in order to prepare the HA sol for HA coating. Two concentrations of HA in solution were controlled at $1 \mathrm{mg} / \mathrm{mL}$ and $5 \mathrm{mg} / \mathrm{mL}$. During the process, stirring and heating was also required to completely dissolve the hydroxyapatite in order to achieve a clear, homogeneous sol. Cylinder samples $(\phi 6.2 \mathrm{~mm}$ $\times 30 \mathrm{~mm}$ ) were fabricated by SLM Solutions using the "best parameter" (scanning speed $800 \mathrm{~mm} / \mathrm{s}$, laser power $230 \mathrm{~W}$ ), and the samples were then sliced into discs of $0.5 \mathrm{~mm}$ thickness by use of a precision cutting machine. The discs were polished and ultrasonically cleaned in acetone, absolute ethyl alcohol, and deionized water, in that sequence. The cast samples were also prepared in the same way. The HA coating was developed using a spin coater to deposit a uniform and single layer to the substrate. The rotation speed was set at $1500 \mathrm{r} / \mathrm{min}$ and, spin time was set at $20 \mathrm{~s}$ [38-40]. After each spin-coating process was done, the 316L/HA disc was placed on a hot electronic plate with a temperature of $50{ }^{\circ} \mathrm{C}$ for $1 \mathrm{~min}$. The same operation was repeated ten times to develop 10 layers of HA coating. The coated sample was then put into a drying oven at $100{ }^{\circ} \mathrm{C}$ for $1 \mathrm{~h}$, followed by a sintering in the vacuum furnace according to the sintering pattern shown in Figure 3. After that, the top- and side-view images of the HA coating were observed by using SEM. A CETR-UMT Pin-on-Disk tribometer was used to test the 316L/HA discs. The as-printed and as-cast samples were also put into the vacuum sintering furnace for de-stress annealing. The surface roughness of the as-printed, as-cast, and 316L/HA discs were measured by using a Bruker 3-D profiler (ContourTG-K0). Five measurements with a scan area of $0.09 \times 0.12 \mathrm{~mm}^{2}$ were performed at random positions on 3 samples $[25,41]$.

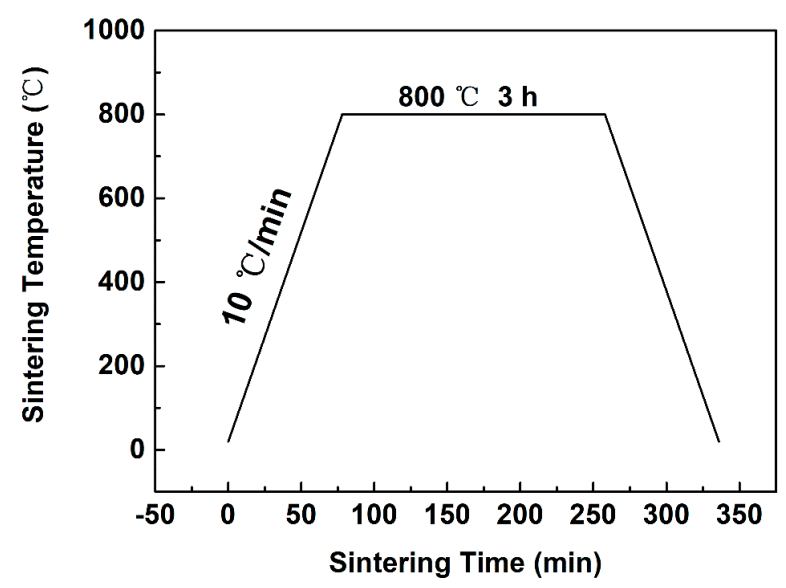

Figure 3. Sintering curve for HA (hydroxyapatite) coating on the as-printed 316L stainless steel substrate. 


\subsection{Cell Culture and Proliferation Study}

After high-temperature sterilization $\left(200^{\circ} \mathrm{C}\right)$, the $316 \mathrm{~L} / \mathrm{HA}$ discs were placed in 96 -well Tissue Culture Polystyrenes (TCPS) plates. One of the control groups had the same culture medium but without the metal materials (just TCPS and culture medium), while the rest of the test groups had the same culture medium but were filled with as-printed 316L discs [39,42]. The blank group contained only PBS (Phosphate Buffered Saline) without cell suspension and materials. L929 cells (Mouse fibroblast cell line, purchased from the Shanghai Type Culture Collection, Chinese Academy of Sciences) were used for the biocompatibility study, and were cultured at $37{ }^{\circ} \mathrm{C}$ in a $5 \% \mathrm{CO}_{2}$ air atmosphere until the cells were ready to be sub-cultured. After digesting with Trypsin-EDTA solution (0.25\% Trypsin- $0.53 \mathrm{mM}$ EDTA solution), single-cell suspension was counted by using the Countess II Automated Cell Counter. The cell suspension was diluted to a concentration of $1.0 \times 10^{4}$ cells $/$ well. After preparation, $0.2 \mathrm{~mL}$ of the cell suspension was seeded into each well [43-45].

The discs were washed twice by PBS, and cell proliferation of each group was measured after being cultured for $24 \mathrm{~h}, 72 \mathrm{~h}$, and $120 \mathrm{~h}$. $0.2 \mathrm{~mL}$ of fresh culture medium and $0.02 \mathrm{~mL}$ of CCK-8 (Cell Counting Kit-8, purchased from the Dojindo of Japan) solution were added to each well and incubated at $37{ }^{\circ} \mathrm{C}$ for $2 \mathrm{~h}$. The Optical Density (OD) value of the solution in each well was then determined using the Varioskan LUX multimode microplate reader (Thermo scientific, Waltham, MA, USA), at a wavelength of $450 \mathrm{~nm}$. Subsequently, cell Relative Growth Rate (RGR) was calculated using the following method [43]:

$$
R G R=\frac{A_{s}-A_{b}}{A_{c}-A_{b}}
$$

where $A_{s}$ is the OD value of the experimental group, $A_{\mathrm{C}}$ is the OD value of the control group, and $A_{b}$ is the OD value of the blank group.

\subsection{Cell Morphology Study}

The discs were cleaned twice using PBS, fixed with $4 \%$ paraformaldehyde for 40 min, stained with DAPI $(30 \mu \mathrm{g} / \mathrm{mL})$ for $15 \mathrm{~min}$, and then cleaned twice more with PBS. Magnified fluorescence micrographs of the samples were acquired.

\subsection{Statistical Comparisons for the Biocompatibility Study}

To further evaluate biocompatibility, statistical comparisons were performed using Student's $t$ test for unpaired data. $P<0.05$ was considered to be significant for most tests [43].

\section{Results}

\subsection{Powder Characterization}

Figure $4 \mathrm{a}, \mathrm{b}$ show the particle size distribution (Figure $4 \mathrm{a}$ ) and SEM image (Figure $4 \mathrm{~b}$ ) of the 316L stainless steel powders, respectively. The metal powders are nearly spherical, and their size distribution follows the Gaussian distribution, with a medium diameter of $\sim 37.2 \mu \mathrm{m}$. Figure $4 \mathrm{c}$ shows the TEM morphology of the nano-hydroxyapatite powders, suggesting that they are rod-shaped with a length of $\sim 100 \mathrm{~nm}$ and width of $\sim 20 \mathrm{~nm}$.

\subsection{Density of the As-Printed 316L Steel}

Figure 5a shows the impact of the laser power on the relative density of the SL Med samples. It is noted that the maximum density was achieved at a laser power of $230 \mathrm{~W}$. The laser energy density (total energy input per volume of each track), $E\left(\mathrm{~J} / \mathrm{mm}^{3}\right)$, can be calculated by [17]:

$$
E=\frac{P}{V}
$$


where $P$ is the incident laser power $(\mathrm{W})$ and $V$ is the volume of laser scanning per second $\left(\mathrm{mm}^{3} / \mathrm{s}\right)$. In this work, $V$ can be estimated by [18]:

$$
V=v \times D \times L
$$

where $v$ is the incident scanning speed $(800 \mathrm{~mm} / \mathrm{s}), D$ is the layer thickness $(30 \mu \mathrm{m})$, and $L$ is the beam size $(50 \mu \mathrm{m})$. The best laser energy density value can then be determined as $191.7 \mathrm{~J} / \mathrm{mm}^{3}$. The laser energy density in the literature [10] ranges from $100 \mathrm{~J} / \mathrm{mm}^{3}$ to $180 \mathrm{~J} / \mathrm{mm}^{3}$. A slightly higher laser energy density was adopted here, varying from $166.7 \mathrm{~J} / \mathrm{mm}^{3}$ to $216.7 \mathrm{~J} / \mathrm{mm}^{3}$, as higher laser energy density normally leads to better as-printed density. This finding is also consistent with other literature [21]. Figure 5b-d shows the optical images of the three 316L stainless steel samples under different laser energy densities: $166.7 \mathrm{~J} / \mathrm{mm}^{3}(200 \mathrm{~W}), 191.7 \mathrm{~J} / \mathrm{mm}^{3}(230 \mathrm{~W})$, and $216.7 \mathrm{~J} / \mathrm{mm}^{3}(260 \mathrm{~W})$. Below $191.7 \mathrm{~J} / \mathrm{mm}^{3}$, the laser energy density is too low to melt the powders completely and to realize good density. When the laser energy density rises to $216.7 \mathrm{~J} / \mathrm{mm}^{3}$, an overheated reaction may result in the molten pool region, which could in turn infuse spatter and gas evaporation and therefore create poorer density [44,45].
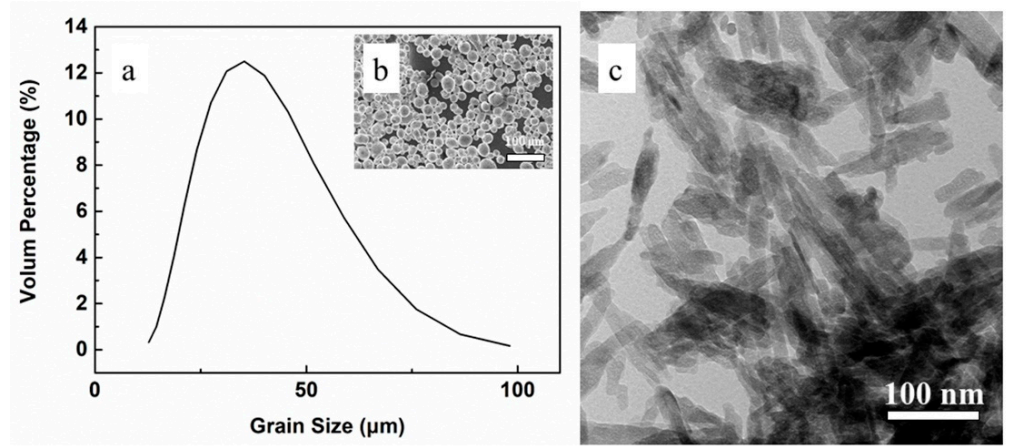

Figure 4. (a) Particle size distribution and (b) SEM (Scanning Electron Microscopy) image of 316L stainless steel powder, (c) TEM (Transmission Electron Microscope) morphology of the nano-hydroxyapatite powders.

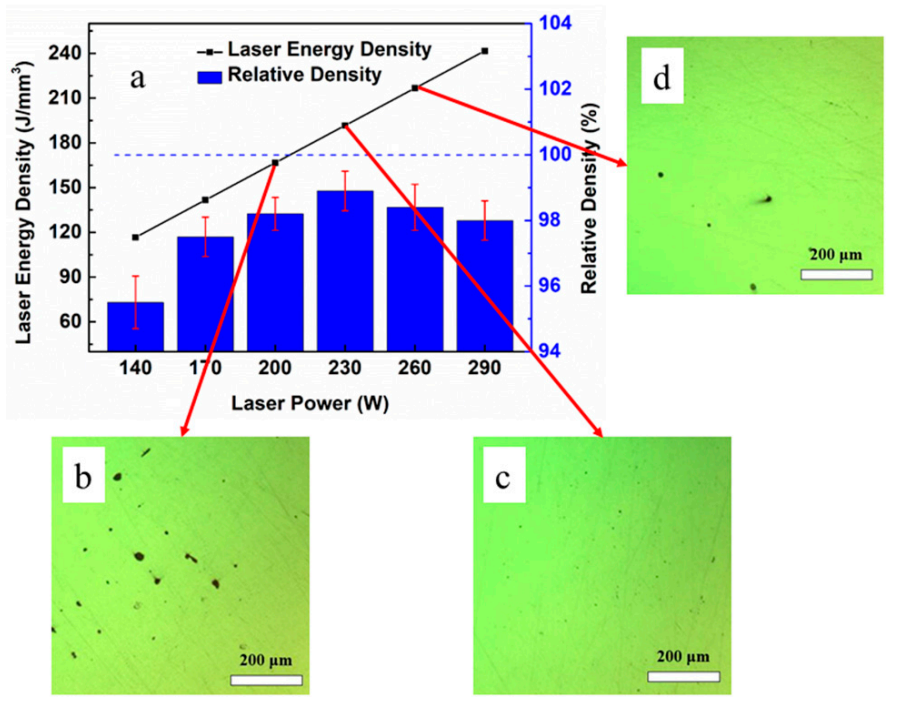

Figure 5. (a) Relative density of the 6 samples manufactured by SLM (selective laser melting); Optical microscope images of 316L stainless steel under three different laser energy densities: (b) $166.7 \mathrm{~J} / \mathrm{mm}^{3}$ (200 W), (c) $191.7 \mathrm{~J} / \mathrm{mm}^{3}$ (230 W), and (d) $216.7 \mathrm{~J} / \mathrm{mm}^{3}(260 \mathrm{~W})$. 
Meanwhile, the X-ray diffraction (XRD) results (Figure 6) suggest that the listed as-printed 316L stainless steels mainly contain $\gamma$-Fe with an austenite structure (the unlisted samples share the same pattern). The three crystal planes, (111), (200), and (220), show strong peaks in all the XRD patterns. Specific data regarding crystal plane (111) is listed in Table 2. Compared with standard austenite (PDF card information regarding the austenite phase), the $2 \theta$ as-printed samples shifted to a relatively higher value. The diffraction peak intensity of crystal plane (111) increased with energy density. It is likely that the promoted thermal stress in the sample, which may be attributed to the higher temperature and larger pool size, resulted in a change to the diffraction peak intensity [45], while a reduction in the FWHM (full width at half maximum) may have been an indication of the higher energy density resulting from the grain coarsening [46]. At the same time, the right shift of the diffraction pattern is an indication that the lattice parameter of the crystal shrinks [47]. According to Brag's Law $(2 \mathrm{~d} \sin \theta=\mathrm{n} \lambda)$, the right shift of the diffraction pattern (towards the larger $2 \theta$ angle) indicates that the lattice parameter of the crystal shrinks (smaller lattice parameters) when the wavelength $\lambda$ keeps constant. The shrinkage of the lattice parameters may be due to the residual compression stress inside the as-printed 316L stainless steels.

Table 2. XRD (X-ray diffraction) data of $2 \theta$, intensity and peak FWHM (full width at half maximum) of the peak at crystal plane (111).

\begin{tabular}{cccc}
\hline Sample & $\mathbf{2 \theta}$ & Intensity & FWHM \\
\hline Standard & 43.582 & & \\
$140 \mathrm{~W}$ & 43.695 & 2369 & 0.201 \\
$170 \mathrm{~W}$ & 43.55 & 2357 & 0.241 \\
$200 \mathrm{~W}$ & 43.568 & 2437 & 0.234 \\
$230 \mathrm{~W}$ & 43.696 & 3956 & 0.203 \\
$260 \mathrm{~W}$ & 43.657 & 4548 & 0.199 \\
$290 \mathrm{~W}$ & 43.64 & 5058 & 0.180 \\
\hline
\end{tabular}

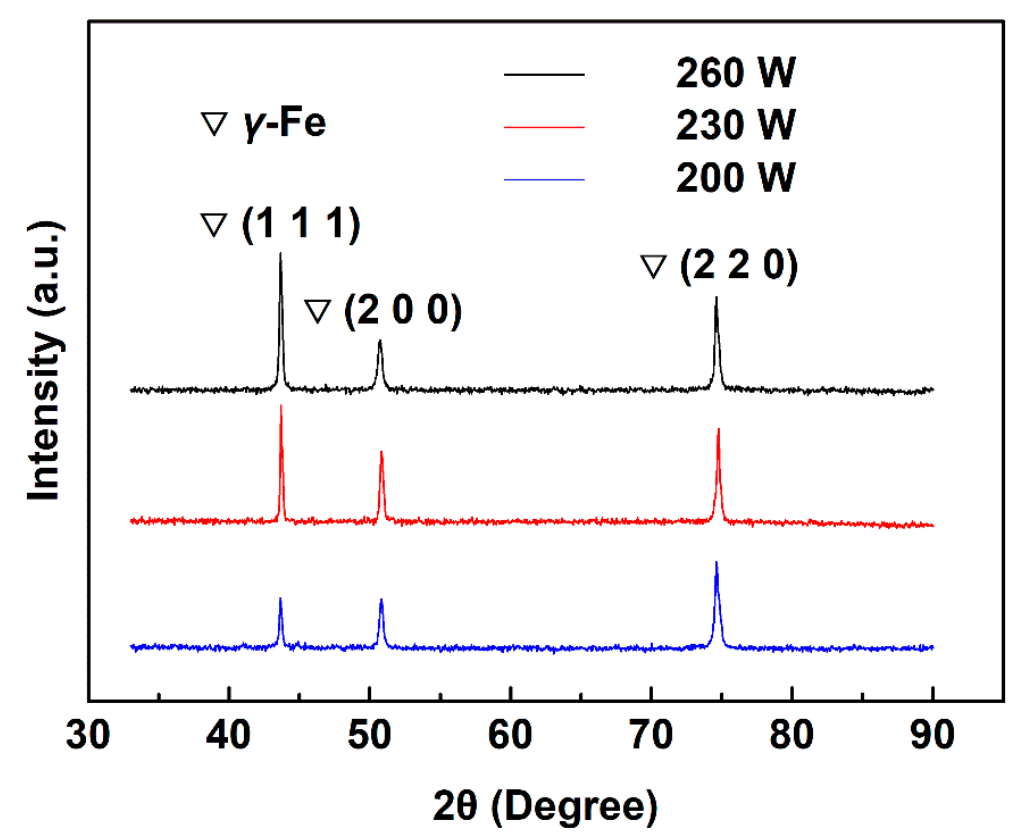

Figure 6. XRD patterns of specimens under different types of laser power.

\subsection{Microstructure and Mechanical Properties of the As-Printed 316L Stainless Steel}

The EBSD results of the horizontal plane (XOY plane) (Figure 7a) suggest that the average grain size of as-printed samples is $\sim 13.5 \mu \mathrm{m}$, which is 10 times smaller than the as-cast sample $(\sim 146.9 \mu \mathrm{m}$; 
Figure $7 \mathrm{~b}$ ). The cause of this phenomenon (where the level of mechanical properties is higher for printed samples than cast) is likely to be because of the grain refinement in the as-printed sample.
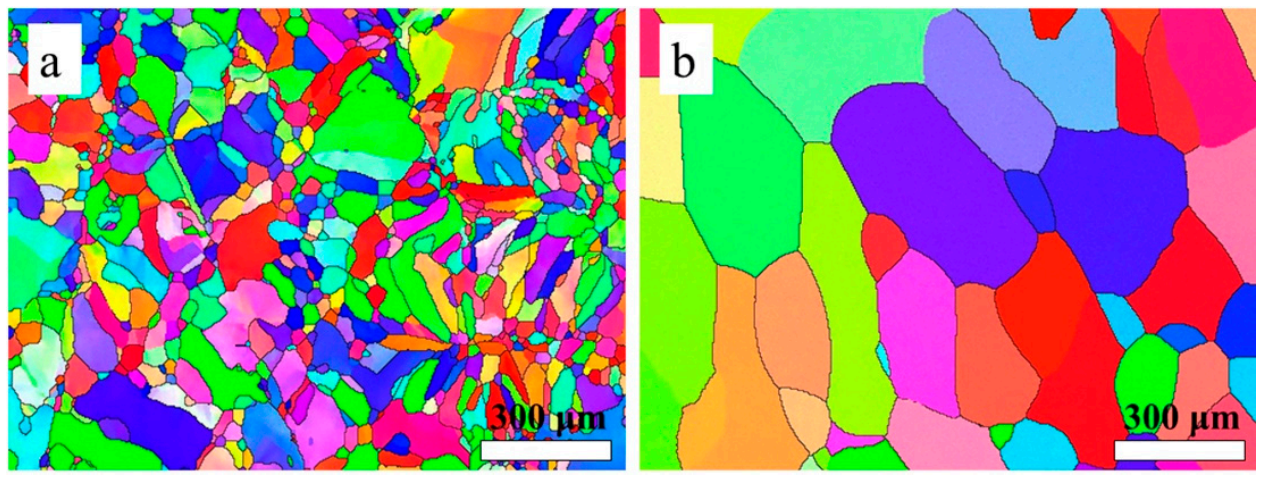

Figure 7. EBSD (Electron Backscattered Diffraction) image of (a) as-printed sample; (b) as-cast sample.

Figure 8 shows the relationship between the laser power and Vickers hardness of the as-printed samples. It should also be noted that the Vickers hardness shows the same trend as the variation of relative density. The Vickers hardness of the as-cast 316L stainless steel is around $200 \mathrm{HV}$, while the micro-hardness of the as-printed samples (with the maximum value of $245 \mathrm{HV}$ ) are all higher than $200 \mathrm{HV}[48,49]$.

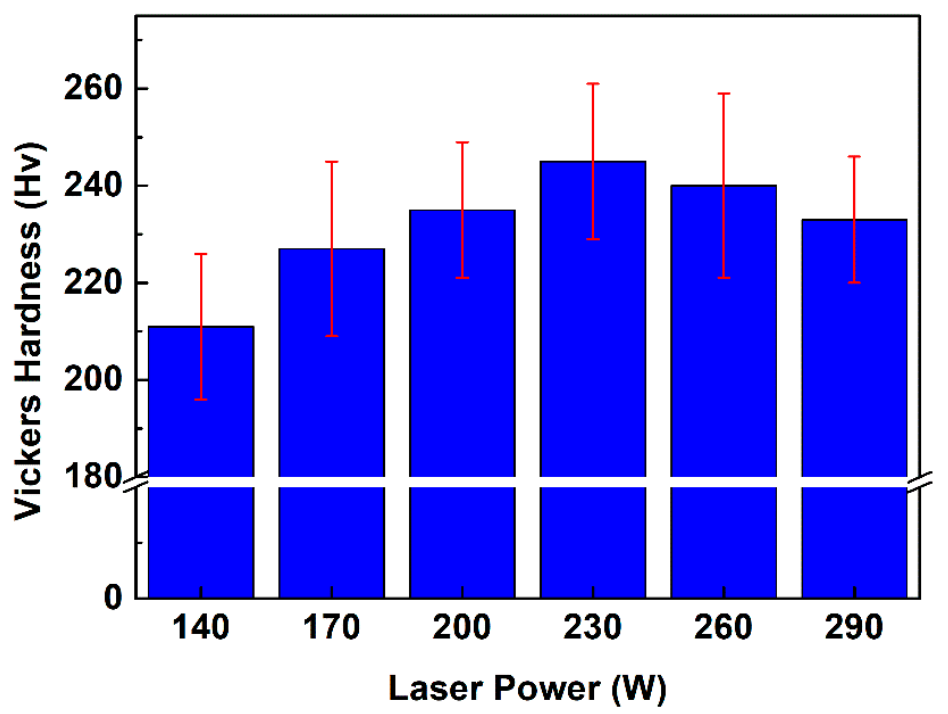

Figure 8. Vickers hardness of the 316L stainless steel samples manufactured by SLM.

Figure 9a shows the typical tensile stress-strain curves of the six samples. Both the tensile strength and elongation are shown in Figure $9 \mathrm{~b}$. It is noted that when the laser power is above $170 \mathrm{~W}$, the as-printed samples shows higher tensile strength than the as-cast samples (649.8 MPa). The sample of $230 \mathrm{~W}$ shows the highest tensile strength $(\sim 730 \mathrm{MPa})$ and the corresponding elongation is $\sim 38.8 \%$. Tensile strength generally increases along with laser power, but the modulus is shown to keep steady at $214.2 \mathrm{GPa}$. Based on this, the strengthening mechanism of the as-printed samples may be considered as fine-grain strengthening (average grain size: as-printed sample $\sim 13.5 \mu \mathrm{m}$, as-cast sample $\sim 146.9 \mu \mathrm{m}$; Figure $7 \mathrm{~b}$ ) and the density of samples has played a dominant role in regard to its mechanical properties. Figure $9 \mathrm{~b}$ also shows that the as-printed samples' elongation increases at first, and then decreases. Some as-printed samples' elongation is lower than that of the as-cast samples. 
The fracture surface morphologies are observed by SEM in order to identify the ductile fracture and some ductile dimples, as shown in Figure 10. It can be seen that the fracture surface with a laser power of $170 \mathrm{~W}$ shows larger voids and unmelted powder particles compared with that of higher laser power. The defects, voids included, are always considered to be the parts to trigger a failure in the tensile process [49-51]. In addition, the unmelted powder particles existing in the small voids (marked by the arrow in Figure 10c) are attributed to the incomplete melting under insufficient laser irradiation. The ductile dimples of the fracture surface microstructure are presented in Figure 10d. The mechanical properties of the as-printed 316L in this study (hardness at 200-250 Hv, tensile strength at 600-700 MPa, and elongation at $\sim 40-60 \%$ ) are within the same level as the data presented in the literature [10,21]. Ours are slightly lower in hardness, which might be due to a higher laser energy density applied and a resultant enlarged grain size.
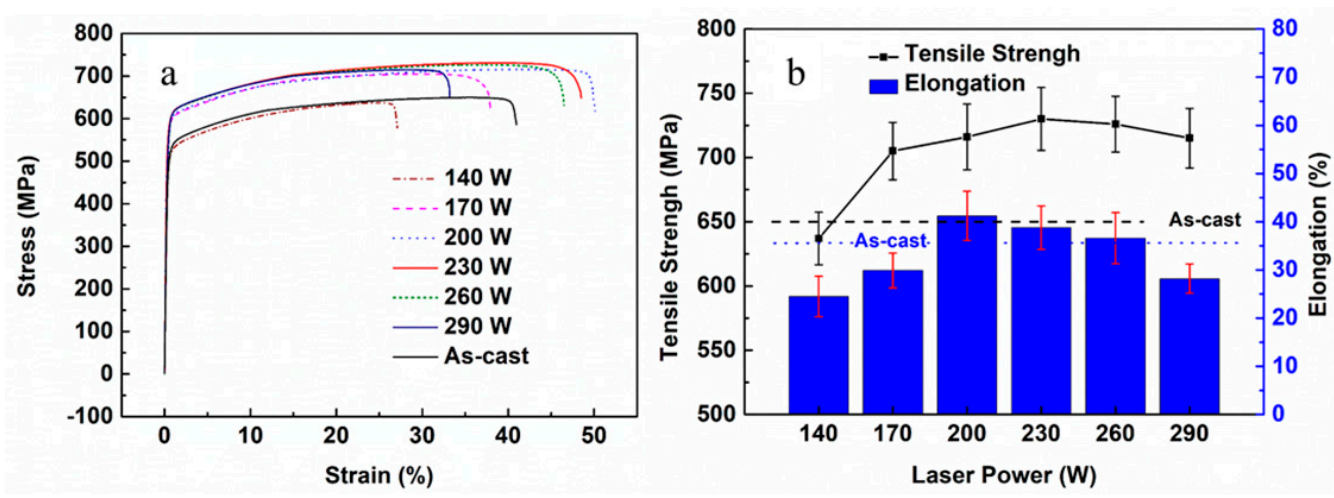

Figure 9. (a) Typical stress-strain curve of the $170 \mathrm{~W}$ samples, (b) tensile strength and elongation of the 316L stainless steel samples.
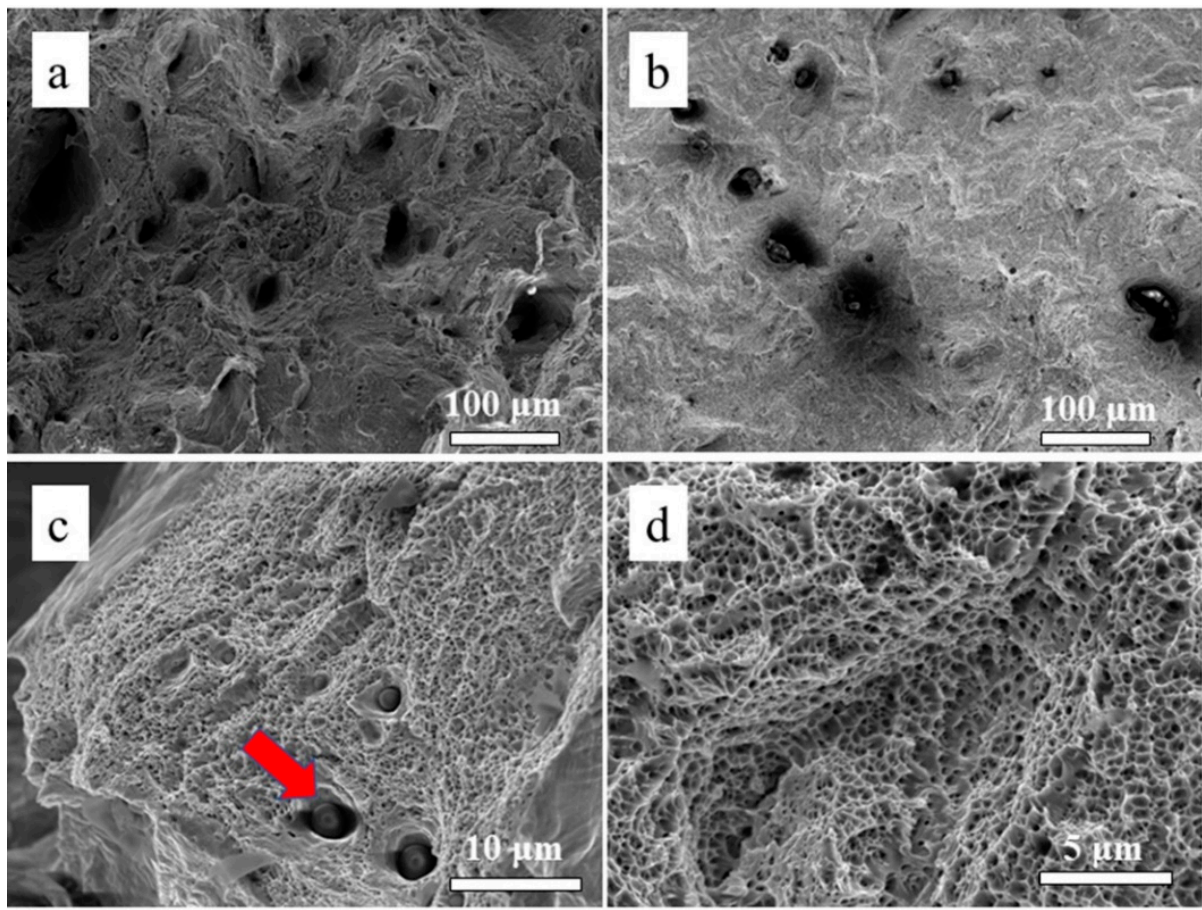

Figure 10. Fracture morphology of SLM-processed 316L tensile samples: (a) laser power of $200 \mathrm{~W}$; (b) laser power of $170 \mathrm{~W}$; (c) magnification of fracture surfaces with laser power of $170 \mathrm{~W}$ and (d) ductile dimple fracture with laser power of $170 \mathrm{~W}$. 
The cohesive strength of the HA coating was acquired by the CETR-UMT Pin-on-Disk tribometer. A $200-\mu \mathrm{m}$ radius diamond indenter was used to conduct the scratching test. The critical load to the indenter was $9.7 \mathrm{~N}$ at a scratch speed of $2 \mathrm{~mm} / \mathrm{min}$ along a $2 \mathrm{~mm}$ distance [52].

\subsection{Biocompatibility of the As-Printed 316L Stainless Steel}

SEM images of the cast HA coating are shown in Figure 11. The side-view images (Figure 11a,b) illustrate that the coating thickness of the sample was $\sim 7.5 \mu \mathrm{m}$ ( $1 \mathrm{mg} / \mathrm{mL}$ solution) or $\sim 11.83 \mu \mathrm{m}$ (5 mg/mL solution). The top-view images of the two different HA coating samples are shown in Figure 11c,d. It is noted that the sample of $1 \mathrm{mg} / \mathrm{mL} \mathrm{HA}$ sol performed well with no redundant agglomerated HA particles on the coating surface. The samples of $1 \mathrm{mg} / \mathrm{mL}$ HA sol were then selected in the following work.
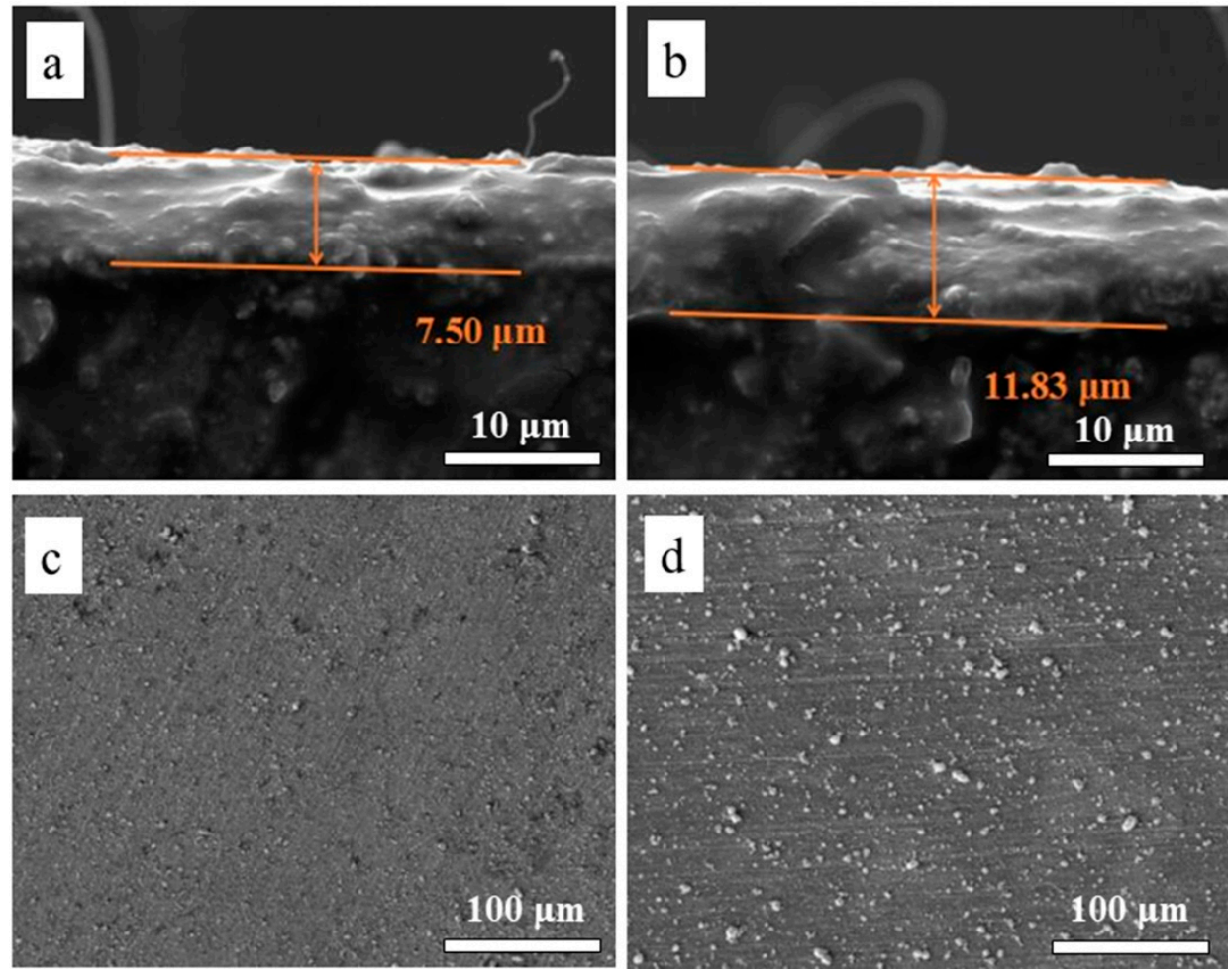

Figure 11. HA coating thickness (a) $1 \mathrm{mg} / \mathrm{mL}$ solution (b) $5 \mathrm{mg} / \mathrm{mL}$ solution, and surface morphology (c) $1 \mathrm{mg} / \mathrm{mL}$ solution $(\mathbf{d}) 5 \mathrm{mg} / \mathrm{mL}$ solution.

According to the corresponding standard (GB/T16886.5-2003 [53]), the cytotoxicity grade was divided into four grades. Among them, grade 0 ( $R G R \geq 100 \%$ ) means that the biomaterials present good biocompatibility, and grade $1(75 \% \leq$ RGR $<100 \%)$ means that the biomaterials exhibit no cell cytotoxicity. Both grades 0 and 1 suggest that the biomaterials qualify as implant materials. The proliferation tendencies of the 316L/HA, as-printed, and as-cast 316L stainless steel and TCPS after $24 \mathrm{~h}, 72 \mathrm{~h}$, and $120 \mathrm{~h}$ of culturing are shown in Figure 12. It is noted that the 316L/HA samples exhibit the highest RGR, and in general the as-printed samples display better bioactivity than the as-cast samples. The cytotoxicity levels of both samples are either grade 0 or 1 . On the other hand, the cell viability on the 316L/HA samples and the as-printed samples is significantly higher than the as-cast samples. These results indicate that all the samples present no cell cytotoxicity according to the RGR value, but the 316L/HA samples and the as-printed samples appear to have better biocompatibility than the as-cast samples, suggesting that the as-printed 316L stainless steel shows promise as good biomedical implant materials. 


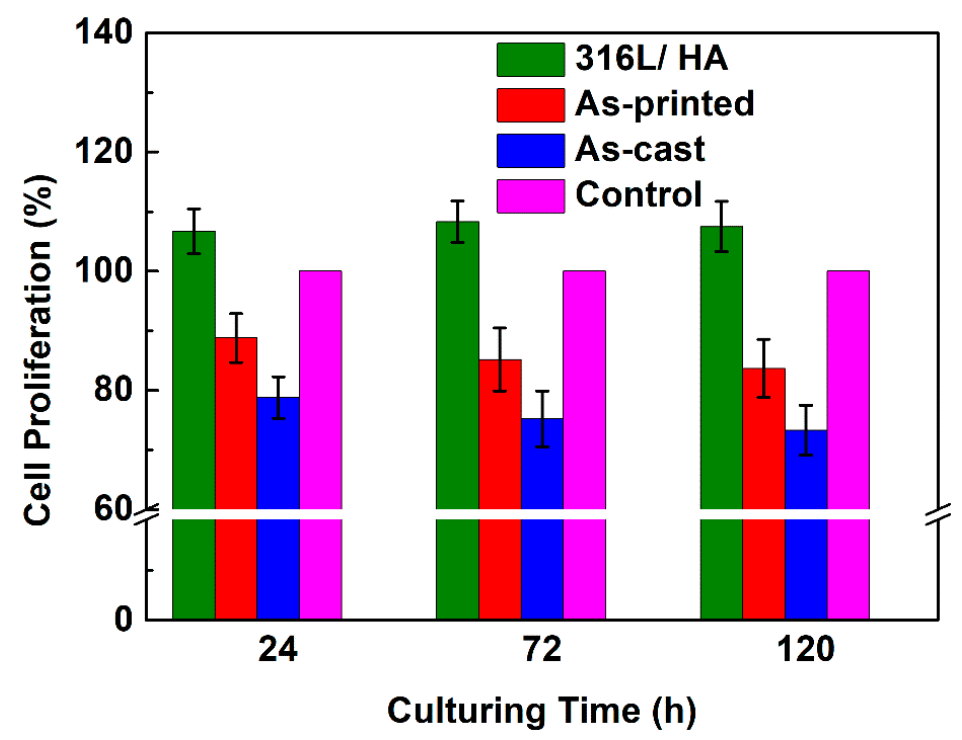

Figure 12. The cell proliferation tendency.

The cell morphologies on the 316L/HA samples after $120 \mathrm{~h}$ of culturing are shown in Figure 13. In this figure, the cell shape and spreading behavior in the four groups are shown to be quite similar to each other. This result suggests that the cells in each group almost reach a complete adhesion to the 316 matrix. Compared with the 316L/HA and the as-printed 316L stainless steel, the cells cultured on the as-cast samples shown in Figure 13c exhibit a near-round shape with less spreading. The 316L/HA and as-printed 316L stainless steel similarly show that the toxicity grade worsens as culturing time increases.
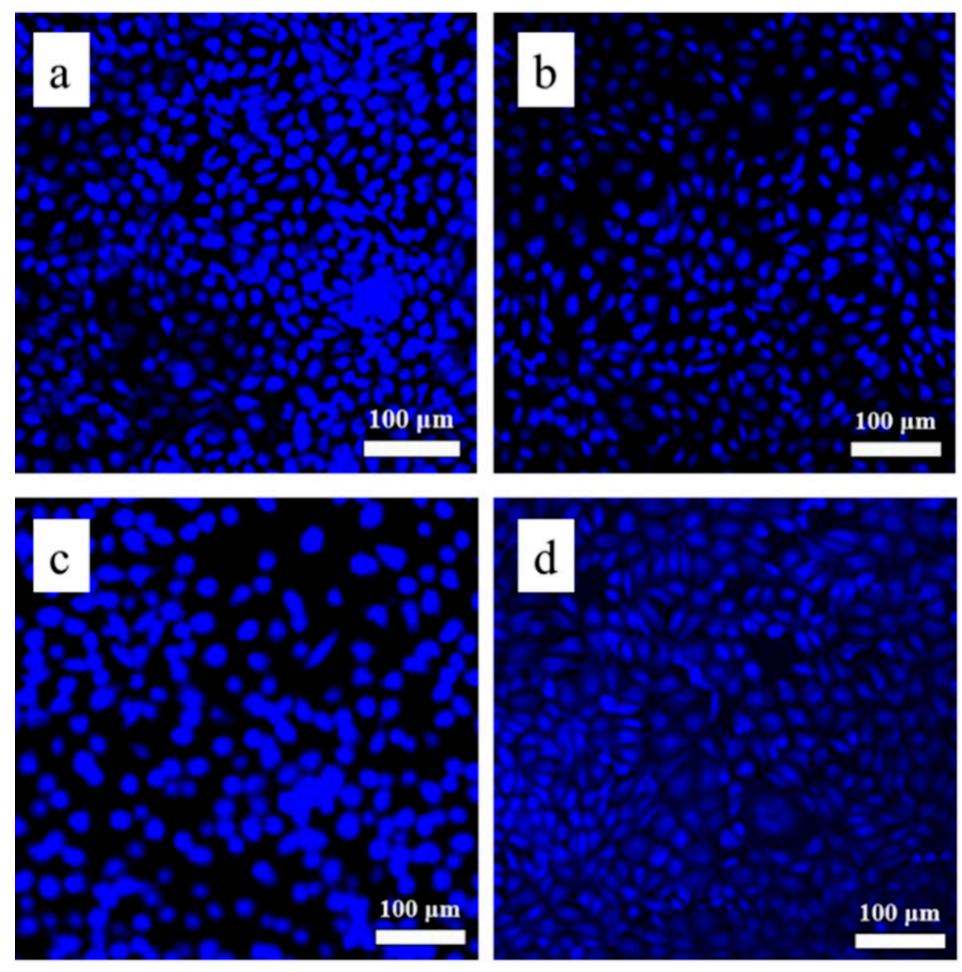

Figure 13. L929 cells' morphology on (a) 316L/ HA 316L/HA, (b) as-printed 316L stainless steel, (c) as-cast 316L stainless steel and (d) TCPS (Tissue Culture Polystyrenes). 
The cell densities after $120 \mathrm{~h}$ of culturing was measured by Image J, and the result is shown in Figure 14. For the same sample, three different points were tested, and the result is statistically different. Compared to what is outlined in the literature [25], the cell density of the as-printed and as-cast groups is shown to stay on the same level $\left(\sim 40,000\right.$ cells $\left./ \mathrm{cm}^{2}\right)$. The cell density of the $316 \mathrm{~L} / \mathrm{HA}$ group is $\sim 69,800$ cells $/ \mathrm{cm}^{2}$, which is a little lower than that of the control group $\left(\sim 72,300\right.$ cells $\left./ \mathrm{cm}^{2}\right)$. This phenomenon likely occurred because the roughness of the HA coating prevented the confocal microscope to focus on the same plane. This probably caused the brightness of some cells' morphologies to be too dim to be recognized by Image J. The real cell density of the 316L/HA group should be larger than 72,300 cells $/ \mathrm{cm}^{2}$.

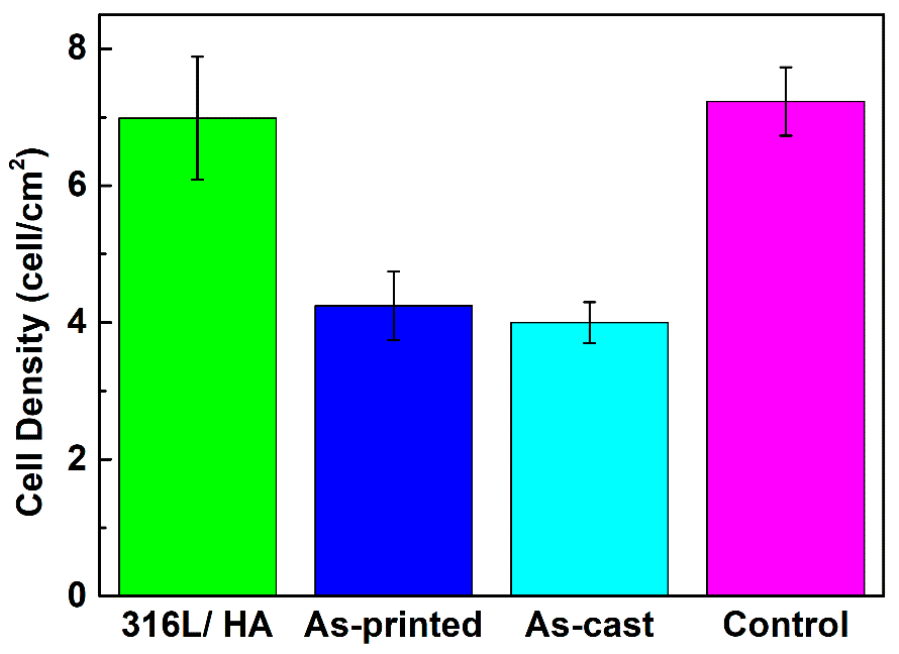

Figure 14. The cell densities after $120 \mathrm{~h}$ of culturing.

\section{Discussion}

\subsection{Discussion on the Surface Roughness and Cellular Activities}

In this study, evaluation of the as-printed samples' RGR values generally showed that they had better biocompatibility than the as-cast samples. This result is consistent with the data in literature [21]. One reason for there being such a difference between the as-printed and as-cast samples is likely because of the higher level of surface roughness for the as-printed samples. Further experiments on proteins adsorption are needed to fully understand this phenomenon.

A Bruker 3-D profiler (ContourTG-K0) was used to measure the surface roughness of the samples. The 3-D profiler images (Figure 15a-c) and the average surface roughness (Figure 15d) are showed in Figure 14. Figure 15c represents the expected smooth surface for the as-cast sample. While the effect of the metallurgical defects or voids (dark dot in Figure 15b) increased the surface roughness for the as-printed sample, after the coated HA, the 316L and HA sample revealed different surface topographies (Figure 15c). The numerous peaks and valleys on the coated surface greatly increased the average Ra value to $3.3 \mu \mathrm{m}$ (Figure 15d). Due to the higher surface roughness and enlarged surface area of the as-printed sample, it was able to adsorb more proteins and better mediate cell adhesion than the as-cast ones $[54,55]$. This is also likely to be the reason why the as-printed sample exhibited better bioactivity than the as-cast sample by RGR value. 

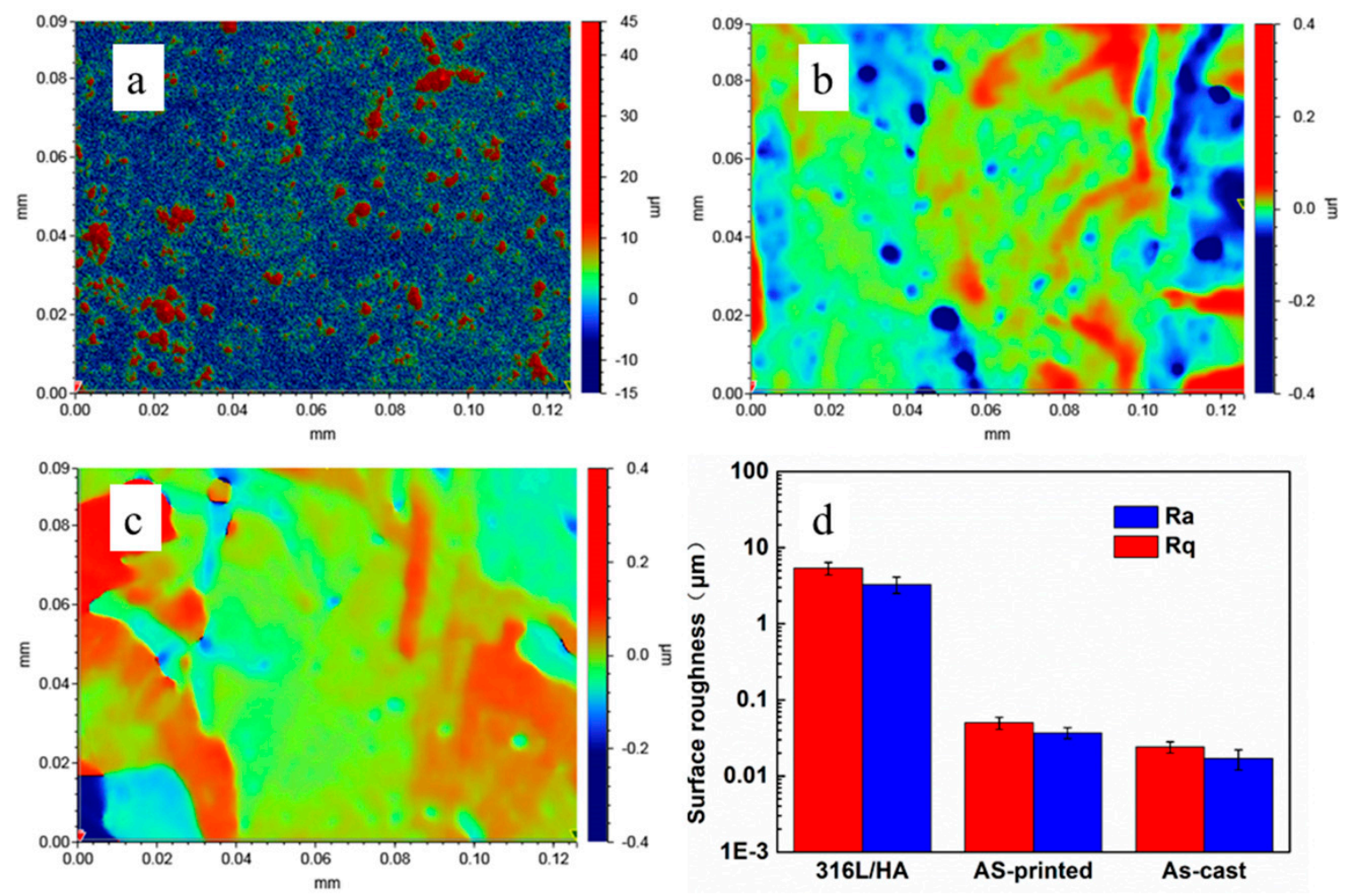

Figure 15. 3-D profiler images of (a) 316L/HA, (b) as-printed 316L, (c) as-cast 316L and (d) the average surface roughness.

\subsection{Discussion on the Biocompatibility of the $316 L+H A$}

The 316L/HA samples exhibited excellent bioactivity, which is likely because the HA coating prevented iron release from the 316L stainless steel. To confirm this, the suspension from each group was collected after the culturing was completed, and nitrate was digested by using a water bath heated to $90{ }^{\circ} \mathrm{C}$ for $45 \mathrm{~min}$. Filtered with $0.2 \mu \mathrm{m}$ of filter membrane, the release of $\mathrm{Fe}, \mathrm{Ni}, \mathrm{Cr}$, $\mathrm{Mn}$ and Mo ions from each experimental group were measured by Agilent 7700x Inductively Coupled Plasma Mass Spectrometry (ICP-MS, Santa Clara, CA, USA).

ICP-MS results show that few Fe $(\sim 1.69 \mu \mathrm{g} / \mathrm{L})$ and $\mathrm{Cr}(\sim 0.36 \mu \mathrm{g} / \mathrm{L})$ ions could be tested in the control group (culture medium). These were deducted from the original data, and the resulting $120 \mathrm{~h}$ culturing iron-releasing results are shown in Figure 16. Figure 16 shows that the outward diffusion of metal ions can be effectively blocked by HA coating, from 316L stainless steel to cell culture medium. Figure 16a shows that the release of Fe ions largely contributes to all five ions' release, and this release decreases after the alloys are coated. The release from as-printed 316L stainless steel is slightly higher than that of as-cast 316L stainless steel. The $\mathrm{Mn}$ and $\mathrm{Cr}$ ion release (coated $\sim 30-40 \mu \mathrm{g} / \mathrm{L}$, uncoated $\sim 80-90 \mu \mathrm{g} / \mathrm{L}$ ), takes up $21 \%$ of all five ions' release, and shares a similar trend with the Fe ion release. The Ni ion release is limited, as there are no significant differences between the release from coated and as-printed 316L. The Mo ion release could hardly be tested, and no significant difference can be observed. Figure $16 \mathrm{~b}$ shows that for the $316 \mathrm{~L} / \mathrm{HA}$, the concentration of the $\mathrm{Cr}$ ion increases sharply in the first $24 \mathrm{~h}$, and the incremental rate of $\mathrm{Cr}$ decreases at $72 \mathrm{~h}$ and $120 \mathrm{~h}$. After $120 \mathrm{~h}$ of culturing, the release of $\mathrm{Cr}$ ions reaches about $38.7 \mu \mathrm{g} / \mathrm{L}$. This phenomenon may lead to an HA coating, and the chromic oxide film (generated in the first $24 \mathrm{~h}$ ) can effectively block the $\mathrm{Cr}$ ion diffusion to cell culture medium. In addition, for bare 316L stainless steel, the release of $\mathrm{Cr}$ ions at $24 \mathrm{~h}, 72 \mathrm{~h}$, and $120 \mathrm{~h}$ share a similar trend with the 316L/HA. Although no significant $(p>0.05)$ difference is observed in the release of $\mathrm{Cr}$ ions between the as-printed and as-cast groups, the amount of $\mathrm{Cr}$ released from all of the bare 
316L stainless steel at 24,72 , and $120 \mathrm{~h}$ is significantly $(p<0.05)$ higher than that released from the 316L/HA.
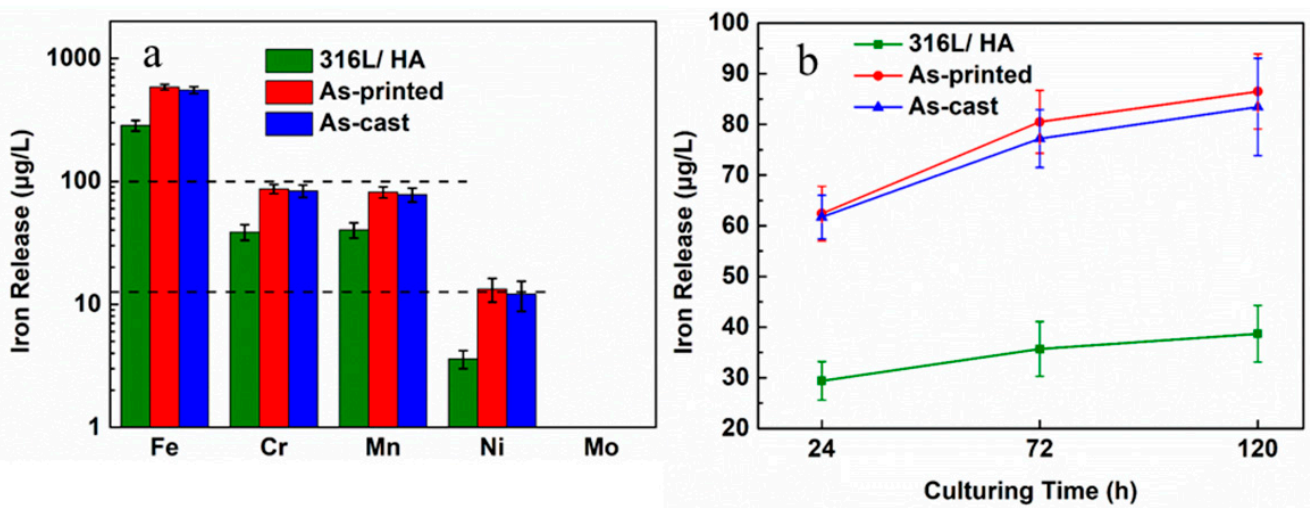

Figure 16. (a) Iron release from 316L/HA, as-printed and as-cast samples for $120 \mathrm{~h}$, (b) the Cr release from 316L/HA, as-printed and as-cast samples for 24, 72, $120 \mathrm{~h}$.

\section{Conclusions}

Biomedical 316L stainless steel has been fabricated using SLM. High-density samples $(98.9 \%$ relative density) have been obtained at $800 \mathrm{~mm} / \mathrm{s}$ scanning speed and $30 \mu \mathrm{m}$ layer thickness, using a $230 \mathrm{~W}$ continuous wavelength laser. The average grain size of an as-printed sample was $\sim 13.5 \mu \mathrm{m}$, the tensile fracture strength of the as-printed 316L stainless steel was $\sim 720.3 \mathrm{MPa}$, and the elastic modulus was $\sim 214.2 \mathrm{GPa}$.

The 316L/HA was fabricated using the sol-gel spin coating method. The thickness of the HA coating on top of the 316L steel is able to be controlled by the concentration of the HA solution if necessary. According to the biocompatibility evaluation results and the RGR value, the 316L/HA presents no cell cytotoxicity and shows better bioactivity than that of the as-printed 316L. The results of this study suggest that SLM and spin coating are capable of producing 316L/HA material with no cell cytotoxicity, while maintaining good bioactivity and mechanical properties.

Author Contributions: J.L., X.J. and R.G. carried out the experiments and analyzed the raw data under the guidance of J.S. and M.Y.; Y.H. and P.Z. contributed to discussion of the results obtained; and J.S. and M.Y. proposed the study and finalized the manuscript.

Funding: This research was funded by the [Shenzhen Science and Technology Innovation Commission] grant number [ZDSYS201703031748354] and [JCYJ20170817110331228], and the [National Science Foundation of Guangdong Province] grant number [2016A030313756]. This work is also supported by the Pico Center at SUSTech, with support from the Presidential fund as well as the Development and Reform Commission of Shenzhen Municipality.

Acknowledgments: The authors acknowledge the technical support from Chunhui Hou and Yuedong Zhang of the Department of Biology, Southern University of Science and Technology (Shenzhen, China).

Conflicts of Interest: The authors declare no conflict of interest.

\section{References}

1. Ehtemam-Haghighi, S.; Prashanth, K.G.; Attar, H.; Chaubey, A.K.; Cao, G.H.; Zhang, L.C. Evaluation of mechanical and wear properties of Ti-xNb-7Fe alloys designed for biomedical applications. Mater. Des. 2016, 111, 592-599. [CrossRef]

2. Baddoo, N.R. Stainless steel in construction: A review of research, applications, challenges and opportunities. J. Constr. Steel Res. 2008, 64, 1199-1206. [CrossRef]

3. Ziewiec, A.; Tasak, E.; Witkowska, M.; Ziewiec, K. Microstructure and properties of welds of semi-austenitic precipitation hardening stainless steel after heat treatment. Arch. Metall. Mater. 2013, 58, 613-617. [CrossRef] 
4. Ehtemam-Haghighi, S.; Lu, H.B.; Jian, G.Y.; Cao, G.H.; Habibi, D.; Zhang, L.C. Effect of $\alpha^{\prime \prime}$ martensite on the microstructure and mechanical properties of beta-type Ti-Fe-Ta alloys. Mater. Des. 2015, 76, 47-54. [CrossRef]

5. Barnes, D.; Johnson, S.; Snell, R.; Best, S. Using scratch testing to measure the adhesion strength of calcium phosphate coatings applied to poly (carbonate urethane) substrates. J. Mech. Behav. Biomed. Mater. 2012, 6, 128-138. [CrossRef] [PubMed]

6. Okulov, I.V.; Volegov, A.S.; Attar, H.; Bönisch, M.; Ehtemam-Haghighi, S.; Calin, M.; Eckert, J. Composition optimization of low modulus and high-strength TiNb-based alloys for biomedical applications. J. Mech. Behav. Biomed. Mater. 2017, 65, 866-871. [CrossRef] [PubMed]

7. Frazier, W.E. Metal Additive Manufacturing: A Review. J. Mater. Eng. Perform. 2014, 23, 1917-1928. [CrossRef]

8. Yarlagadda, P.K.; Chandrasekharan, M.; Shyan, J.Y.M. Recent advances and current developments in tissue scaffolding. Bio-Med. Mater. Eng. 2005, 15, 159-177.

9. Miranda, G.; Faria, S.; Bartolomeu, F.; Pinto, E.; Madeira, S.; Mateus, A.; Carvalho, O. Predictive models for physical and mechanical properties of 316L stainless steel produced by selective laser melting. Mater. Sci. Eng. A 2016, 657, 43-56. [CrossRef]

10. Wang, D.; Song, C.; Yang, Y.; Bai, Y. Investigation of crystal growth mechanism during selective laser melting and mechanical property characterization of 316L stainless steel parts. Mater. Des. 2016, 100, 291-299. [CrossRef]

11. Sumita, M.; Hanawa, T.; Teoh, S.H. Development of nitrogen-containing nickel-free austenitic stainless steels for metallic biomaterials. Mater. Sci. Eng. A 2004, 24, 753-760. [CrossRef]

12. Savalani, M.M.; Hao, L.; Dickens, P.M.; Zhang, Y.; Tanner, K.E.; Harris, R.A. The effects and interactions of fabrication parameters on the properties of selective laser sintered hydroxyapatite polyamide composite biomaterials. Rapid Prototyp. J. 2012, 18, 16-27. [CrossRef]

13. Geiger, F.; Kunze, K.; Etter, T. Tailoring the texture of IN738LC processed by selective laser melting (SLM) by specific scanning strategies. Mater. Sci. Eng. A 2016, 661, 240-246. [CrossRef]

14. Carter, L.N.; Martin, C.; Withers, P.J.; Attallah, M.M. The influence of the laser scan strategy on grain structure and cracking behaviour in SLM powder-bed fabricated nickel superalloy. J. Alloys Compd. 2014, 615, 338-347. [CrossRef]

15. Duraccio, D.; Mussano, F.; Faga, M.G. Biomaterials for dental implants: Current and future trends. J. Mater. Sci. 2015, 50, 4779-4812. [CrossRef]

16. Xin, X.Z.; Xiang, N.; Chen, J.; Wei, B. In vitro biocompatibility of Co-Cr alloy fabricated by selective laser melting or traditional casting techniques. Mater. Lett. 2012, 88, 101-103. [CrossRef]

17. Zhou, Y.H.; Lin, S.F.; Hou, Y.H.; Wang, D.W.; Zhou, P.; Han, P.L.; Yan, M. Layered surface structure of gas-atomized high $\mathrm{Nb}$-containing TiAl powder and its impact on laser energy absorption for selective laser melting. Appl. Surf. Sci. 2018, 441, 210-217. [CrossRef]

18. Yan, J.J.; Zheng, D.L.; Li, H.X.; Jia, X.; Sun, J.F.; Li, Y.L.; Yan, M. Selective laser melting of H13: Microstructure and residual stress. J. Mater. Sci. 2017, 52, 12476-12485. [CrossRef]

19. Attar, H.; Ehtemam-Haghighi, S.; Kent, D.; Wu, X.; Dargusch, M.S. Comparative study of commercially pure titanium produced by laser engineered net shaping, selective laser melting and casting processes. Mater. Sci. Eng. A 2017, 705, 385-393. [CrossRef]

20. Attar, H.; Ehtemam-Haghighi, S.; Kent, D.; Okulov, I.V.; Wendrock, H.; Bönisch, M.; Volegov, A.S.; Calin, M.; Eckert, J.; Dargusch, M.S. Nanoindentation and wear properties of Ti and Ti-Tib composite materials produced by selective laser melting. Mater. Sci. Eng. A 2017, 688, 20-26. [CrossRef]

21. Kong, D.; Ni, X.; Dong, C.; Lei, X.; Zhang, L.; Man, C.; Li, X. Bio-functional and anti-corrosive 3D printing 316L stainless steel fabricated by selective laser melting. Mater. Des. 2018, 152, 88-101. [CrossRef]

22. Bartolomeu, F.; Buciumeanu, M.; Pinto, E.; Alves, N.; Carvalho, O.; Silva, F.S.; Miranda, G. 316L stainless steel mechanical and tribological behavior-a comparison between selective laser melting, hot pressing and conventional casting. Addit. Manuf. 2017, 16, 81-89. [CrossRef]

23. Čapek, J.; Machova, M.; Fousova, M.; Kubásek, J.; Vojtěch, D.; Fojt, J.; Ruml, T. Highly porous, low elastic modulus 316L stainless steel scaffold prepared by selective laser melting. Mater. Sci. Eng. C 2016, 69, 631-639. [CrossRef] [PubMed] 
24. Biemond, J.E.; Hannink, G.; Verdonschot, N.; Buma, P. Bone ingrowth potential of electron beam and selective laser melting produced trabecular-like implant surfaces with and without a biomimetic coating. J. Mater. Sci. Mater. Med. 2013, 24, 745-753. [CrossRef] [PubMed]

25. Bagherifard, S.; Hickey, D.J.; De-Luca, A.C.; Malheiro, V.N.; Markaki, A.E.; Guagliano, M.; Webster, T.J. The influence of nanostructured features on bacterial adhesion and bone cell functions on severely shot peened 316L stainless steel. Biomaterials 2015, 73, 185-197. [CrossRef] [PubMed]

26. Shang, Y.; Yuan, Y.; Li, D.; Li, Y.; Chen, J. Effects of scanning speed on in vitro biocompatibility of 316L stainless steel parts elaborated by selective laser melting. Int. J. Adv. Manuf. Technol. 2017, 92, 4379-4385. [CrossRef]

27. Bayraktaroglu, E.; Gulsoy, H.O.; Gulsoy, N.; Er, O.; Kilic, H. Effect of boron addition on injection molded 316L stainless steel: Mechanical, corrosion properties and in vitro bioactivity. Bio-Med. Mater. Eng. 2012, 22, 333-349.

28. Köse, C.; Kacar, R. In vitro bioactivity and corrosion properties of laser beam welded medical grade AISI 316L stainless steel in simulated body fluid. Int. J. Electrochem. Sci. 2016, 11, 2762-2777. [CrossRef]

29. Kattimani, V.S.; Kondaka, S.; Lingamaneni, K.P. Hydroxyapatite-past, present, and future in bone regeneration. Bone Tissue Regener Insights 2016, 6, 9. [CrossRef]

30. Ramires, P.A.; Wennerberg, A.; Johansson, C.B.; Cosentino, F.; Tundo, S.; Milella, E. Biological behavior of sol-gel coated dental implants. J. Mater. Sci. Mater. Med. 2003, 14, 539-545. [CrossRef] [PubMed]

31. Paital, S.R.; Dahotre, N.B. Calcium phosphate coatings for bio-implant applications: Materials, performance factors, and methodologies. Mater. Sci. Eng. R Rep. 2009, 66, 1-70. [CrossRef]

32. Ergün, Y.; Başpınar, M.S. Effect of acid passivation and $\mathrm{H} 2$ sputtering pretreatments on the adhesive strength of sol-gel derived Hydroxyapatite coating on titanium surface. Int. J. Hydrog. Energy 2017, 42, 20420-20429. [CrossRef]

33. Metikoš-Huković, M.; Tkalčec, E.; Kwokal, A.; Piljac, J. An in vitro study of Ti and Ti-alloys coated with sol-gel derived hydroxyapatite coatings. Surf. Coat. Tech. 2003, 165, 40-50. [CrossRef]

34. Li, X.P.; O'Donnell, K.M.; Sercombe, T.B. Selective laser melting of Al-12Si alloy: Enhanced densification via powder drying. Addit. Manuf. 2016, 10, 10-14. [CrossRef]

35. Vaithilingam, J.; Goodridge, R.D.; Hague, R.J.; Christie, S.D.; Edmondson, S. The effect of laser remelting on the surface chemistry of Ti6al4V components fabricated by selective laser melting. J. Mater. Process. Technol. 2016, 232, 1-8. [CrossRef]

36. Suyalatu, X.; Takayoshi, N.; Norio, H.; Hitoshi, S. Microstructure and mechanical properties of ti-x alloys fabricated by selective laser melting process for new biomaterial devices. Front. Bioeng. Biotechnol. 2016, 4. [CrossRef]

37. Niinomi, M. Recent metallic materials for biomedical applications. Metall. Mater. Trans. A 2002, 33A, $477-486$. [CrossRef]

38. Wierzbicki, A.; Cheung, H.S. Molecular modeling of inhibition of hydroxyapatite by phosphocitrate. THEOCHEM 2000, 529, 73-82. [CrossRef]

39. Hornberger, H.; Virtanen, S.; Boccaccini, A.R. Biomedical coatings on magnesium alloys-A review. Acta Biomater. 2012, 8, 2442-2455. [CrossRef] [PubMed]

40. Su, Y.; Li, G.; Lian, J. A chemical conversion hydroxyapatite coating on AZ60 magnesium alloy and its electrochemical corrosion behaviour. Int. J. Electrochem. Sci. 2012, 7, 11497-11511.

41. Evans, S.L.; Gregson, P.J. Composite technology in load-bearing orthopaedic implants. Biomaterials 1998, 19, 1329-1342. [CrossRef]

42. Pellino, G.; Sciaudone, G.; Caserta, V.; Candilio, G.; Gilda Serena, D.F.; Gagliardi, S.; Landino, I.; Patturelli, M.; Riegler, G.; Di Caprio, E.L.; et al. Fatigue in inflammatory bowel diseases: Relationship with age and disease activity. Int. J. Surg. 2014, 12, S60-S63. [CrossRef] [PubMed]

43. Pang, X.; Casagrande, T.; Zhitomirsky, I. Electrophoretic deposition of hydroxyapatite-CaSiO ${ }_{3}-\mathrm{chitosan}$ composite coatings. J. Colloid Interface Sci. 2008, 330, 323-329. [CrossRef] [PubMed]

44. Xiao, X.F.; Liu, R.F.; Tang, X.L. Electrophoretic deposition of silicon substituted hydroxyapatite coatings from n-butanol-chloroform mixture. J. Mater. Sci. Mater. Med. 2008, 19, 175-182. [CrossRef] [PubMed]

45. Hinds, G.; Wickström, L.; Mingard, K.; Turnbull, A. Impact of surface condition on sulphide stress corrosion cracking of 316L stainless steel. Corros. Sci. 2013, 71, 43-52. [CrossRef] 
46. Vashista, M.; Paul, S. Correlation between full width at half maximum (FWHM) of XRD peak with residual stress on ground surfaces. Philos. Mag. 2012, 92, 4194-4204. [CrossRef]

47. Simonovski, I.; Nilsson, K.F.; Cizelj, L. Crack tip displacements of microstructurally small cracks in 316L steel and their dependence on crystallographic orientations of grains. Fatigue Fract. Eng. Mater. Struct. 2007, 30, 463-478. [CrossRef]

48. Martínez, S.; Lamikiz, A.; Ukar, E.; Calleja, A.; Arrizubieta, J.A.; Lacalle Lopez de, L.N. Analysis of the regimes in the scanner-based laser hardening process. Opt. Lasers Eng. 2017, 90, 72-80. [CrossRef]

49. Martínez Krahmer, D.; Polvorosa, R.; López de Lacalle, L.N.; Alonso-Pinillos, U.; Abate, G.; Riu, F. Alternatives for Specimen manufacturing in Tensile Testing of Steel Plates. Exp. Tech. 2016, 40, 1555-1565. [CrossRef]

50. Herzog, D.; Seyda, V.; Wycisk, E.; Emmelmann, C. Additive manufacturing of metals. Acta Mater. 2016, 117, 371-392. [CrossRef]

51. Zhong, Y.; Liu, L.; Wikman, S.; Cui, D.; Shen, Z. Intragranular cellular segregation network structure strengthening 316L stainless steel prepared by selective laser melting. J. Nucl. Mater. 2016, 470, 170-178. [CrossRef]

52. Hao, L.; Dadbakhsh, S.; Seaman, O.; Felstead, M. Selective laser melting of a stainless steel and hydroxyapatite composite for load-bearing implant development. J. Mater. Process. Technol. 2009, 209, 5793-5801. [CrossRef]

53. Yu, S.; Wang, B.; Pan, Y.; Chen, Z.; Meng, F.; Duan, S.; Ma, W. Cleaner production of spherical nanostructure chromium oxide $\left(\mathrm{Cr}_{2} \mathrm{O}_{3}\right)$ via a facile combination membrane and hydrothermal approach. J. Cleaner Prod. 2018, 176, 636-644. [CrossRef]

54. Yang, D.; Lü, X.; Hong, Y.; Xi, T.; Zhang, D. The molecular mechanism for effects of TiN coating on NiTi alloy on endothelial cell function. Biomaterials 2014, 35, 6195-6205. [CrossRef] [PubMed]

55. Yang, D.; Lü, X.; Hong, Y.; Xi, T.; Zhang, D. The molecular mechanism of mediation of adsorbed serum proteins to endothelial cells adhesion and growth on biomaterials. Biomaterials 2013, 34, 5747-5758. [CrossRef] [PubMed]

(c) 2018 by the authors. Licensee MDPI, Basel, Switzerland. This article is an open access article distributed under the terms and conditions of the Creative Commons Attribution (CC BY) license (http:/ / creativecommons.org/licenses/by/4.0/). 